\title{
The Use of ICT in Public and Private Institutions of Higher Learning, Malaysia
}

\author{
Siti Rafidah Muhamat Dawam \\ Faculty of Computer Sciences and Mathematics, Universiti Teknologi MARA Kedah \\ P.O.Box 187, 08400 Merbok, Kedah, Malaysia
}

Tel: 60-4-456-2462 E-mail: srafidah192@kedah.uitm.edu.my

Khairul Adilah Ahmad

Faculty of Computer Sciences and Mathematics, Universiti Teknologi MARA Kedah

P.O.Box 187, 08400 Merbok, Kedah, Malaysia

Tel: 60-4-456-2450 E-mail: adilah475@kedah.uitm.edu.my

Kamaruzaman Jusoff (Corresponding author)

Faculty of Forestry, Universiti Pertanian Malaysia, 43000 Serdang, Selangor, Malaysia

Tel: 60-3-8946-7176 E-mail: kjusoff@yahoo.com

Taniza Tajuddian

Faculty of Computer Sciences and Mathematics, Universiti Teknologi MARA Kedah

P.O.Box 187, 08400 Merbok, Kedah, Malaysia

Tel: 60-4-456-2461Ｅ-mail: taniza@kedah.uitm.edu.my

Shamsul Jamel Elias

Faculty of Computer Sciences and Mathematics, Universiti Teknologi MARA Kedah

P.O.Box 187, 08400 Merbok, Kedah, Malaysia

Tel: 60-4-456-2181Ｅ-mail: shamsulje@kedah.uitm.edu.my

\author{
Suhardi Wan Mansor \\ English Language Department, Universiti Teknologi MARA Kedah \\ P.O.Box 187, 08400 Merbok, Kedah, Malaysia \\ Tel: 60-4-456-2190Ｅ-mail: suhardiwm@kedah.uitm.edu.my
}

\begin{abstract}
This study examines the extent of ICT utilization among the members of Faculty A of four public higher learning institutions (IPTA) and seven private higher learning institutions (IPTS) in Northern Malaysia. Its focus is on a) to investigate the extent of ICT resources provided by universities authorities, b) focus on types and extent of ICT usage in daily activities, c) to explore the ICT proficiencies level and d) to investigate the level of ICT integration in teaching activities. A total of 76 responses out of 77 from IPTA and only 105 out of 108 responses of IPTS are usable for further analysis in this study. Findings indicate that in the IPTA, though the facilities provided are not as plenty as in IPTS, the
\end{abstract}


level of usage is quite encouraging. While in the IPTS, the levels of ICT usage among the educators are still not satisfactorily. Results also indicated that usage frequencies are more prone on informative in nature, besides integrating computer technology. Furthermore, the study also indicates that there were considerable differences in the use of ICT by educators in their perceived proficiencies and integrating computer technology. This study could be improved by expanding the total sampling population to all faculties in both universities. Methods of analysis could also be varied beyond the descriptive analysis done. Factors that could hinder the level of ICT usage by the educators could also be studied.

Keywords: ICT, Usage, Resources, Frequencies, Proficiencies, Integration

\section{Introduction}

The first computer system in Malaysia was implemented in 1996 (Chan, 2002). Since then, the Government has introduced various initiatives to facilitate the greater adoption and diffusion of ICT to improve capacities in every field of business, industry, education, and life in general. These measures include the enhancement of education and training programmes, provision of an environment conducive to the development of ICT, provision of incentives for computerization and automation, and creation of venture capital funds. Currently, Malaysia is in full gear to steer the economy towards a knowledge-based one.

A national broadband master plan to enable the country to have a $50 \%$ penetration rate for broadband services by the year 2007 has also been implemented. The government sees enhanced networking as vital for the e-learning initiative undertaken by the government to accelerate the growth of education in the country and in ensuring that the country makes the transition towards becoming a knowledge-based society.

The Ministry has formulated three main policies for ICT in education. Whereby, the second policy emphasizes on the role and function of ICT in education as a teaching and learning tool, as part of a subject, and as a subject by itself. Apart from using radio and television as a teaching and learning tool, this policy stresses the use of the computer for accessing information, communication, and as a productivity tool. ICT as part of a subject refers to the use of software (e.g. AutoCAD and SCAD) in subjects such as "Invention" and "Engineering Drawing." ICT as a subject refers to the introduction of subjects such as "Information Technology" and "Computerization".

Despite of the efforts carried out by the Malaysian government on ICT, according to Schank (2007), modern technology has had very little effect on educators' conceptions of teaching and learning. Besides that, institution authorities have spent millions of ringgit in investment to equip their centres with educational technologies such as computer lab, LCD projector, networking or other computer peripherals like printers and modems to assist teaching and preparations of teaching materials. Moreover, some have engaged professionals to give computer courses to their academic staff in preparation to step up as world-class university. As indicated and found in a few studies cited below, this survey would like to look into the Malaysian Higher Institution scenario of ICT utilization among their educators.

Through Internet and accredited technology journals, it is widely discussed and known that higher institutions and schools in America and other developed countries had been integrating the technology into their classrooms (Neo et. al, 2001, Al-Seghayer, 2001 and Nikolova, 2002). The benefits of it are undoubtedly very significant. Students are said to be more eager and highly motivated (Samad, 1997) because they can access their learning anywhere and at anytime provided they have a computer. A study conducted by Chris Rother (2003) a vice president of Education of CDW.G found that $86 \%$ of their respondents who are students said in class computers have improved their academic performance and $74 \%$ said it has increased their attention in class. In fact, $65 \%$ of the teacher respondents who responded to the survey said that computers can be more effective than teachers in conveying certain types of information to the students (Rother, 2003). However, the effectiveness of ICT usage still depends on the teachers and the students in which both parties must be interested and willing to engage with computers (Jones, 1999) and how teachers integrate computer activity in a meaningful learning activity (Demetriadis, 2003). Computers alone might not be sufficient as it needs the integration of the technology product and activities (Samad, 1997). A study conducted by Davis et al (1997) found the quality of the learning can be significantly enhanced when ICT is integrated with teaching.

In reality, most instructors have some familiarity with computers and are able to use a variety of computer softwares as found in one study done by the National Education Association. It was found out that $94 \%$ of all respondents in the survey are able to search the Internet. However, they do not know how to fuse computer skills into classroom instruction. As a study conducted by Cuban (1999) reported, out of every 10 teachers in U.S., fewer than two seriously are users of computers and other information technologies in their classrooms (several times a week); three to four are occasional users (about once a month); and the rest (4-5 teachers out of every 10) never use the machines at all. As another findings from a survey on Survey of ICT utilization in Philippines Public High School' stated that 92\% of the respondents who are teachers of the public school said that there is a need for more information given to them on how to use ICT to support the curriculum and $96 \%$ of the respondents need to develop skills to hands on activity to share with their students (Tinio, 2002). A study conducted by Ahmad (2007), in Open University Malaysia (OUM) in 2006, found out that '....the more 
senior learners prefer mostly face-to-face interactions and are not too comfortable with online courseware and interactions.' However this finding contradicts with a research findings conducted by Bee Theng, Lau and Chia Hua, Sim (2008), whereby the age has a negative relationship with the extent of ICT use among teachers. Senior teachers were found to be highly positive towards ICT use in their teaching and professional work, and had translated this into a greater use of ICT in schools. The teachers' computer competency have an overall mean of $3.35(\mathrm{SD}=0.71)$, indicates that teachers generally feel competent in utilizing ICT tools in school. Another study on ICT implementation in Malaysia, conducted by Shamsul et.al (2006) focused only on the implementation of ICT vision, plan policies and strategies.

Technology can play various instructional roles - and it is the responsibility of the instructors to decide how to best use technology to support student learning. Having a complete infrastructure of the ICT will go meaningless if it is not utilized to the fullest capacity. Meanwhile, Schwach (2004) and Demetriadis et. al (2003) argue that the effective use of technology in classroom is not only limited to the teachers' perceptions on how to use technology is class but also through professional development for teachers. Their study indicates that training is needed in order for teachers to be able to integrate computer in their classroom practice.

The general objective of the study is to explore on the ICT utilizations among the IPTA and IPTS educators of northern Malaysia. The specific objectives of this study are three folds: a) to investigate the extent of ICT resources provided by universities authorities, b) focus on types and extent of ICT usage in daily activities, c) to explore the ICT proficiencies level and d) to investigate the level of ICT integration in teaching activities.

\section{Method}

A survey instrument was designed to gather information on the computer usage adapted from two previous studies done by Victoria L. Tinio in 'Survey of Information and Communication Technology Utilization in Philippine Public High Schools' in 2002 and 'Faculty Responses on the Status of Technology at Southern Mississippi University' in March 2001. The questionnaire was edited and rephrased to suit our research objectives and the infrastructure of Malaysia Public and Private Higher Learning Institutions.

All together there were 90 questions to be answered. The types of questions used in the questionnaire vary from close-ended, scales to matrix questions. A reliability test was also carried out to determine the internal consistency between items used in the questionnaire namely Cronbach's Alpha and all of the questions asked had values of 0.7 and above. It means that they were relevant and significant to our objectives.

Frequency and duration are the most common scales used to measure usage. The questionnaire requires the respondents to provide the estimated time spent daily on computer to perform certain activities. Based on pilot study revealed that the duration of individual session on the computer were highly variable. Therefore, duration was used as the operational definition of usage categories. Meanwhile, frequency was used to give a measure of the specific types of activities for which the respondents used the computer. These activities include integration of computer technology in teaching, instructional activities, communication, organizational activities, creative, expressive, evaluative and informative.

The instrument also measure proficiency level related to computer technologies and integrating information technology in teaching activities. The proficiency level was categorized into five, namely; unfamiliar, beginner, average, advance and expert. Again, five categories have been identified to determine the process level in integrating computer technology namely, awareness, learning, familiarity, adaptation and creative application.

A census survey was conducted on the educators of Faculty A in IPTA and IPTS in the Northern Region of Malaysia which includes the states of Kedah, Penang, and Perak. There are four public higher learning institutions (IPTA Institusi Pengajian Tinggi Awam) and seven private higher learning institutions (IPTS - Institusi Pengajian Tinggi Swasta) that were chosen in this study. From the 250 number of respondents of IPTA, 76 responses have been received. This is about $30.4 \%$ of the population. Whereas, a total of 280 questionnaires were distributed to 7 IPTS's and only 108 were returned. This is about $51.9 \%$ of the population.

\section{Results and discussion}

The findings will be presented in the order of the level of ICT resources, types and extent of ICT usage, level of ICT proficiencies and level of ICT integration in teaching activities.

The professional view on ICT usage in classroom among educators relies heavily on the extensiveness of computer resources availability at their premises. The educators also fairly strongly agree that ICT is a valuable instructional tool and by utilizing it in their preparation for teaching materials and in class teaching will enhance their professional development. They also agree that utilizing ICT in the curriculum will boost their confidence as a competent educator. Furthermore, they also believe that it will promote their development of communication skills in writing and presentation.

\subsection{Level of ICT resources}

The survey also uncovered the fact that the level of ICT resources is still inadequate for academic use for educators. With a mean score of 3.79 for IPTA and 3.9 for IPTS, it shows that the educators' access to those resources is insufficient 
for their educational purposes. This is due to the facts that, majority of the institutions do not have enough ICT resources provided. While according to Pedro (2005), heavy investment in ICT must be taken seriously by university authority in order to improve the teaching quality. He further stated two reasons for such investment. The first reason is university education has a responsibility to ensure the future graduates are well versed in the use of ICT, since in a knowledge economy; such technologies are very important tools of every day life when a student enters the work market. The second reason is that ICT may contribute to more and better learning to improve the effectiveness of university education.

Our finding also revealed that other ICT resources which are considered as important received a low mean score such as LAN (local area network) with 3.49 for IPTA and 3.39 for IPTS. The lowest score is WiFi, receiving a mean score of 2.54 for IPTA and 2.03 for IPTS. (Table 1)

However, as Unwin (2007) observes, “... it is not the availability of the technology which is important, but how it is used" that matters. In order to encourage them integrate the technology into the curriculum, enough resources should be made available to them besides providing courses and workshops to assist them master the related software according to their discipline.

\subsection{Level of ICT usage in daily activities}

Eight aspects of computing purposes were identified in the initial study as being regularly used with the educators: informative, communicative and expressive, integrating computer technology, evaluative instructional, organizational and creative purpose. This study compares the usage frequencies between the IPTA and IPTS educators.

Most of the respondents from IPTA and IPTS are dedicating their daily activities for informative, communicative and expressive purposes (i.e., nearly every day). The informative purposes might include activities such as searching for information over the Internet and CD-ROM; yield the highest frequency for both IPTA and IPTS with percentage response of $60.8 \%$ and $51.9 \%$ respectively. Then followed by communicative purposes such as sending/receiving e-mail, ICQ, computer conferencing and using LCD projector and expressive purposes which include activities such as word processing (typing, editing, layout), and slide presentation. (Table 2)

The result is consistent with a study done by Chong et al (2005) that showed most of the educators use computer on a regular basis for common computer packages such as word processing, spreadsheet, and for internet services such as search engine. This is supported by a study by Yasmin, Wan Suriyani and Sidi Merican (2008) who found educators in UniKL commonly used computer slides presentation and reading materials from web site.

Surprisingly, only fewer number of respondents claimed of using higher level skills activities such as evaluative (e.g. assignments, portfolio, testing), instructional (e.g. drill practice, tutorials, remediation), organizational (e.g. database, spreadsheets, record keeping, lesson plans) and creative (e.g. Desktop publishing, digital video, digital camera, scanners, and graphics) as these activities require specialized knowledge and training in order to use them. However, these activities are vital to educators who really want to incorporate the technology skills with the understanding of the teaching and learning. This finding supported a study which was conducted by Asrun et al (2003) and Castillo (2005) that showed majority of the educators do not use new opportunities that are available in ICT such as graphic application, multimedia and some authoring applications in teaching activities.

\subsection{Level of ICT proficiencies}

Considerable differences were found in the levels of proficiency between the two institutions. Even though the IPTA outnumbered IPTS in terms of ICT resources, however, IPTS outperformed IPTA in terms of ICT level of proficiency. In the IPTA, $48.6 \%$ of lecturers are at average level of ICT proficiency, as compared to $44.8 \%$ of IPTS educators are in the advanced level. Surprisingly, they are $2.8 \%$ of IPTA and $4.8 \%$ of IPTS were in the beginner level despite of their seniority in service. (Table 3)

The study also found that, though the educators claim they are expert / advanced in the level of proficiency, however the ICT resources that can support them into becoming creative applicants of teaching and learning process are insufficient.

\subsection{Level of ICT integration in teaching activities}

The study also attempted to determine the educators' process level in integrating computer technology in their teaching activities. (Table 4) The highest response for both IPTA and IPTS educators fall under the adaptation category. Here the respondents think about the computers as an instructional tool to help them perform appropriate tasks. They are no longer concern about it as a technology. However, educators' who are in this category are able to use many different computer applications to aid them in delivering the required knowledge to their students. Quite a number of the educators from IPTA (around $31.9 \%$ ), as compared to $24.04 \%$ of the educators from IPTS indicated they are in the category of familiarity, which is beginning to understand the process of using technology and can think of specific task in which the technology might be used. Whereas, more IPTS educators were (29.81\%) under the creative application category, as compared to IPTA educators $(22.2 \%)$. In this category, they claim that they can apply their knowledge about the technology in the classroom and able to use them as an instructional aid and able to integrate computers into their curriculum. Among the 
IPTS respondents, none reported as having awareness level of proficiency, but surprisingly, there are $1.4 \%$ of IPTA educators who were just aware that the technology exist but have not used it or perhaps avoiding the technology. This finding is consistent with research done by Asrun (2003) which showed that even though educators have positive attitudes towards ICT usage, however they are not convinced that the use of ICT in teaching will lead to better student outcomes.

Unfortunately, only $22.2 \%$ of IPTA respondents versus $29.8 \%$ of IPTS respondents are actually applying their technology expertise into their learning/teaching process. A majority of them just 'believe' they can use technology in doing their job, but not integrating them yet. We may suggest that this is happening due to the attitude that educators still hold. These educators may feel "very unsure about the effective use of technology" or believe that "computer activities are just a waste of time" (Fryer, 2004).

Another possible reason for such reluctance as Zhang (2007) “....argues that the pedagogical cultures of the East and West are in conflict, causing certain reluctance among Asian nations to adopt ICTs because they are so closely connected with the theory of constructivis."

\section{Conclusion}

From the study conducted, the following conclusions can be derived: a) ICT resources at both institutions are still unsatisfactory to facilitate the teaching and learning activities. b) In terms of ICT usage, most of the educators from both institutions dedicated / spent most of their daily activities for informative, communicative and expressive activities. c) Level of ICT proficiencies among the IPTS educators are higher than the IPTA whereby a majority of IPTS educators claimed to be in the advanced level unlike a majority of IPTA educators who were just in the average level. d) In terms of the level of ICT integration process, most educators from both institutions are under the adaptive category. But a few of the IPTA educators were reported as 'never use' or 'rather avoid' using ICT in their teaching activities.

\section{References}

Ahmad Hashem (2008). ICT Initiatives in Higher Education: The Open University Malaysia (OUM) Perspectives. In ICT Conference and Exhibition, 10-12 March 2008. Kuala Lumpur, Malaysia. Retrieved 22 July 2009 from http://www.moe.gov.my/43seameocc/download/MSIA-OUM.pdf

Allan H.K. Yuen, Nancy Law and K.C. Wong (2003).ICT Implementation And School Leadership: Case Studies Of ICT Integration In Teaching And Learning," Journal of Educational Administration, 41(2): 2003, pp. 161. Retrieved 6 December 2007 from http://www.emeralinsight.com/0957-8234.htm

Al-Segghayer, K. (2001). The Effect of Multimedia Annotation Modes on L2 Vocabulary Acquisition: A Comparative Study. Journal of Language Learning \& technology, 5(1): pp.202-232.

Asrun, M., Dal, M. and Samuel, C. (2003). How do Teachers Use Information and Communication Technology in Iceland high Schools in 2002? International Conference on Computer Science and Technologies - CompSysTech'2003. Sofia, Bulgaria: 19-20 June 2003. Retrieved 2 March 2008 from http://ecet.eces.ru.acad.bg/cst/Docs/proceedings/S4/IV-4.pdf

Bee Theng, Lau and Chia Hua, Sim. (2008). Exploring The Extent of ICT Adoption Among Secondary School Teachers in Malaysia. International Journal of Computing and ICT research. Vol. 2, No. 2, pp.19-36. Retrieved 22 July 2009 from http://www.ijcir.org/volume2-number2/article 3.pdf.

Castillo, N.(2005). The Level of ICT Use and Expertise by Teachers in Chilean Secondary Schools. Retrieved 15 January 2008 from http://www.tise.cl/archivos/tise2006/23.pdf

Chan, Foong-Mae., (2002). ICT in Malaysian Schools: Policy \& Strategies. In Seminar / Workshop on The Promotion Of ICT Education to Narrow the Digital Divide, 15-22 October 2002. Tokyo, Japan.

Chong, C.K., Sharaf Horani and Jacob Daniel, (2005). A study on the use of ICT in Mathematics Teaching. Malaysian Online Journal of Instructional Technology(MOJIT), 2(3): pp 43-51.

Cuban, L., (1999, 4 August). The Technology Puzzle. Education Week, 47, 68. Retrieve 22 November 2003 from http://www.edweek.org/ew/vol-18/43cuban.h18.

Demetriadis, S., et.al., (2003). Culture In Negotiation: Teachers' Acceptance/Resistance Attitudes Considering The Infusion Of Technology Into Schools. Computers \& Education, 41, pp.19-37 in the article of Nadzrah Abu Bakar \& Peter Mickan,(2004). Students' Experience In Computer-Based English Language Classroom, Proceedings Of The 2003 ASIACALL International Conference On IT And Language Education, pp.1-7. Korea.

Jones, J., (1999). Language Learning, Technology and Development: The Essential Interaction Between Teachers And Students. The Fourth International Conference on Language and Development in the article of Nadzrah \& Peter, (2004). Students' Experience In Computer-Based English Language Classroom, Proceedings Of The 2003 ASIACALL International Conference On IT And Language Education, pp: 1-7. Korea.

National Education Association (2000). Retrieved October 12006 from http://www.unionfacts.com/unions 
Neo, M. and K.T.K. Neo. (2001). Innovative Teaching: Using multimedia in a problem-based learning environment. Educational Technology \& Society 4(4)

Nikolova, O.R., (2002). Effect of Students' Participation in Authoring of Multimedia Materials on Students Acquisition of Vocabulary. Language Learning \& Technology.6(1): pp.100-122

Pedro, F.(2005). Higher Education in Europe. Comparing Traditional and ICT-Enriched University Teaching Methods: Evidence from Two Empirical Studies. 30(3-4).

Rother, C.,(2003). Technology's Value in Education. Retrieved September $15 \quad 2004$ from http://www.thejournal.com/articles/_

Samad, R.S.A., (1997). Teknologi Mencambah Minat Pembelajaran. Dewan Budaya. 19(2): pp. 48-49

Schank, R. (2007). Teching In The New Era. In C. Crawford, R. Carlsen, K. McFerrin, J. Price, \& R. Weber (Eds.). Proceedings of Society for Information Technology and Teacher Education International Conference 2007 (Keynote). Chesapeake, VA:AACE.

Schwach, E. (2004). How Do Professional Development Opportunities Assist Teachers In Using Technology In Their Classrooms? 2001, http://users.rcn/com/tinshee/paper.htm in the article of Nadzrah Abu Bakar \& Peter Mickan, Students' Experience In Computer-Based English Language Classroom, Proceedings of the 2003 ASIACALL International Conference on IT and Language Education, Korea, pp. 1-7.

Shamsul, A. M., Rose, A. A., Azizah, A. R., (2006). Rubric For Assessing ICT Vision, Plan, Policies and Standards in Malaysian Higher Education. International Journal of Education and Development using Information and Communication Technology. Vol.3, Issue.2 (2007). pp. 30-56

Tan, C. (2002). Towards A Smart Nation. Jurutera, 2002(4): pp. 6-12

Tinio. Victoria L. (2002). Survey of Information and Communication Technology Utilization in Philippine Public High Schools. Retrieved February 15, 2004 from www.digitalphilippines.org/research_fullarticle

Unwin, A. (2007). The Professionalism of The Higher Education Teacher: What's ICT Got To Do With It? Teaching in Higher Education. 12(3). Pp. 295-308. In Wang, T. Rethinking Teaching With Information and Communication Technologies (ICTs) In Architectural Education. Teacher and Teacher Education (2009), doi: 10.1016/j.tate.2009.04.007

Table 1. Level of ICT resources

\begin{tabular}{lc|c}
\hline Level of ICT resources & $\begin{array}{l}\text { IPTA } \\
\text { mean }\end{array}$ & $\begin{array}{c}\text { IPTS } \\
\text { mean }\end{array}$ \\
\hline Instructor access computer & 3.79 & 3.9 \\
Computer availability & 3.53 & 3.16 \\
Local area network & 3.49 & 3.39 \\
WiFi & 2.54 & 2.03 \\
\hline
\end{tabular}

Table 2. Level of ICT usage in daily activities

\begin{tabular}{|c|c|c|}
\hline Level of ICT usage in daily & IPTA & IPTS \\
\hline activities & $\%$ of response & $\%$ of response \\
\hline Informative & 60.8 & 51.9 \\
\hline Communicative & 50.7 & 41 \\
\hline Expressive & 46.6 & 41.9 \\
\hline Evaluative activities & 32 & 24 \\
\hline Instructional & 25.3 & 22.9 \\
\hline Organizational & 22.4 & 28.6 \\
\hline Creative & 6.7 & 11.5 \\
\hline
\end{tabular}


Table 3. Level of ICT proficiencies

\begin{tabular}{|c|c|c|}
\hline Loul of ICT nuffion & IPTA & IPTS \\
\hline Lever or IC I promciencies & $\%$ of response & $\%$ of response \\
\hline Beginner & 2.8 & 4.8 \\
\hline Average & 48.6 & 43.8 \\
\hline Advanced & 34.7 & 44.8 \\
\hline Expert & 13.9 & 6.7 \\
\hline
\end{tabular}

Table 4. Level of ICT integration in teaching activities

\begin{tabular}{|c|c|c|}
\hline \multirow{2}{*}{ Level of ICT integration } & IPTA & IPTS \\
\hline & $\%$ of response & $\%$ of response \\
\hline Awareness & 1.4 & 0 \\
\hline Learning & 1.4 & 8.65 \\
\hline Familiarity & 31.9 & 24.04 \\
\hline Adaptation & 43.1 & 37.5 \\
\hline Creative Application & 22.2 & 29.81 \\
\hline
\end{tabular}

